\title{
Application time affects synthetic auxins herbicides in tank-mixture with paraquat on hairy fleabane control
}

\author{
Diecson Ruy Orsolin da Silva ${ }^{1 *}$ (D), Adalin Cezar Moraes de Aguiar², Claudir José Basso ${ }^{1}$, Dionei Schmidt Muraro ${ }^{3}$
}

$10.1590 / 0034-737 X 202168030005$

\begin{abstract}
Conyza sp. was the first glyphosate-resistant weed in Brazil's soybean crop. Synthetic auxin herbicides followed by paraquat has improved the hairy fleabane control, and time of day of herbicide application can affect the control efficacy. There are no studies reporting the effects of the application time of synthetic auxins in tank-mixture with paraquat, or in sequential application with paraquat at two growth stages of hairy fleabane, applied at different times of the day. The herbicides were sprayed during the morning and night. 2,4-D applied alone was more effective applied during the day, while dicamba efficiency was higher when applied at night in the rosette stage. The mixture of 2,4-D and paraquat was more efficient when applied during the night. Tall hairy fleabane were more effectively controlled by dicamba + paraquat as well as any synthetic auxin followed by paraquat. When herbicides were applied at night, efficiency was slightly higher.
\end{abstract}

Keywords: Conyza bonariensis; 2,4-D; dicamba; sequential; night application; morning application.

\section{INTRODUCTION}

Conyza sp. was the first glyphosate-resistant weed in Brazil's soybean crop and causes severe yield losses in soybean (Agostinetto et al., 2017). It is estimated that approximately half of the soybean area in the southern and southeastern parts of the country is infested (Lucio et al., 2019). The evolution of glyphosate-resistant weeds has become a global issue problem in agriculture and 2,4-D and dicamba-resistant crops provide an alternative for postemergence applications of synthetic auxins on soybean.

The hairy fleabane (Conyza bonariensis) emergence can occur throughout the year, with peaks in autumn and spring, with various weed size at the time of herbicide application (Vidal et al., 2007). The herbicide efficiency is strongly dependent on the growth stage, and in a previous study, horseweed control was poor when herbicides were sprayed at plant higher than $30 \mathrm{~cm}$ (Kruger et al., 2010). The harvest of winter crops prior to sowing of soybean is associated with the cutting of plants, which reduces leaf area and stimulates sprouting thereby generating new stems. Therefore, the control efficacy may be decreased.

Farmers generally use the tank-mixture herbicide method to improve the weed control, targeting weeds which may be tolerant or less susceptible to a single active ingredient (Lagator et al., 2013). Furthermore, the use of herbicide in sequential application has become a successful strategy for weed management since the application of auxin herbicides followed by paraquat has maximized the hairy fleabane control (Eubank et al., 2008). In previous experiments, glyphosate and 2,4-D were not effective in controlling hairy fleabane but when paraquat was applied followed within 5 days, provided highly effective control (Werth et al., 2010). The sequential application of herbicides has been essential to prevention of plant regrowth.

Herbicide efficacy can vary depending on the time of day of application and weed stage, and can also be weed species-specific. Reduced weed control has been

\footnotetext{
Submitted on October 06th, 2019 and accepted on December 04 ${ }^{\text {th }}, 2020$

${ }^{1}$ Universidade Federal de Santa Maria, Departamento de Ciências Agronômicas e Ambientais, Frederico Westphalen, Rio Grande do Sul, Brazil. diecsonros@hotmail.com; claudirbasso@gmail.com

2 Universidade Federal de Viçosa, Departamento de Fitotecnia, Viçosa, Minas Gerais, Brazil. adalin-cezar@hotmail.com

3 Universidade de São Paulo, Departamento de Entomologia, Piracicaba, São Paulo, Brazil. dioneimuraro@gmail.com

* Author for correspondence: diecsonros@hotmail.com
} 
attributed to large weeds, especially for non-systemic herbicides (Stopps et al., 2013). Conversely, glyphosate a systemic herbicide - provided good control of Artemisia biennis regardless of weed size (Kegode \& Fronning, 2005). Potential reasons for the time of day effect include air temperature, relative humidity, wind speed, leaf angle and circadian cycle (Stopps et al., 2013; Martinson et al., 2002; Martinson et al., 2005; Sellers et al., 2003). The efficacy of herbicides is significantly affected by environmental factors, and herbicides can be applied at sunrise or late in the evening when the temperature, humidity and speed wind are favorable.

Previous research has showed that applications of 2,4$\mathrm{D}$ and dicamba are more effective for horseweed control when applied during the day, while paraquat should be applied in the night (Montgomery et al., 2017). The control efficiency of synthetic auxins and paraquat in tankmixtures might be compromised due to paraquat's mode of action limiting the translocation of auxins to meristematic tissues in daytime applications. However, there is no information on the specific effects of tank-mix herbicides synthetic auxin and paraquat, and additional information is required regarding burndown management. Thus, the objective of this study was to evaluate the effect of synthetic auxins, applied alone, in tank-mixes, or in sequencial with paraquat at differents growth stages of hairy fleabane and time of day.

\section{MATERIALS AND METHODS}

Two experiments were conducted in the greenhouse at Experimental Station of Corteva Agriscience, Mogi Mirin, SP and a field experiment at Federal University of Santa Maria, campus Frederico Westphalen, RS between September of 2016 and January of 2017. In the greenhouse experiment used plastic pots with a capacity of $3 \mathrm{~L}$, containing soil and sand, in a proportion of 2:1. Hairy fleabane seeds were collected from an agricultural area with no proven history of resistance to glyphosate and were planted directly in the pots. After emergence, the seedlings were thinned out, leaving one plant per pot, and kept in the greenhouse for 50 days with the temperature and irrigation controlled until being sprayed with herbicides. The greenhouse was kept at an average temperature of $26{ }^{\circ} \mathrm{C}\left( \pm 2{ }^{\circ} \mathrm{C}\right)$ with daily irrigation throughout the experiment.

In the greenhouse, the experiment was arranged in a two factorial $(10 \times 2)$ in a randomized complete design with four replicates. The factor $A$ was composed of herbicides applied alone: 2,4-D (670 $\mathrm{g}_{\text {ae ha-1 }}$ ), dicamba (378 $\mathrm{g}$ ae ha${ }^{1}$ ), paraquat (400 g ai ha-1), a tank-mixture (+) of 2,4D+paraquat $(670+400)$, dicamba+paraquat $(378+400)$, paraquat $\left(800 \mathrm{~g}\right.$ ai ha-1 $\left.^{-1}\right)$, a sequential application (/) of 2,4D/paraquat (670 / 400), dicamba/paraquat (378 / 400), paraquat/paraquat (400 / $\left.400 \mathrm{~g}_{\text {ai }} \mathrm{ha}^{-1}\right)$, and the factor B was application time: at night and in the morning time. The first herbicide application were applied in the rosette growth stage (15 - 18 leaves). The sequential applications of paraquat were applied at six or seven days after the first application. The pots were moved outside of greenhouse to herbicide spray and subsequently placed back after spraying. The locations, environmental data and application timings are described in Table 1.

In the field, the experiment was arranged in a two factorial $(10 \times 2)$ in a randomized complete block design with four replicates. The factor A was composed of herbicides applied alone: 2,4-D (1005 $\mathrm{g}$ ae ha $\left.{ }^{-1}\right)$, dicamba (720 $\left.\mathrm{g} \mathrm{ae} \mathrm{ha}^{-1}\right), \operatorname{MCPA}\left(879 \mathrm{~g} \mathrm{ae} \mathrm{ha}^{-1}\right)$, a tank-mixture (+) of 2,4-D+paraquat (1005+400), dicamba+paraquat (720+400), MCPA+paraquat $\left(879+400 \mathrm{~g}^{\text {ai }} \mathrm{ha}^{-1}\right)$, a sequential application (/) of 2,4-D/paraquat (1005/400), dicamba/

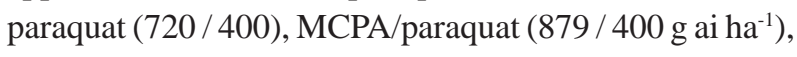
and the factor B was application time: at night and in the morning time. The experiment also included a previous application of glyphosate (isopropylamine salt - $720 \mathrm{~g}$ ae $\mathrm{ha}^{-1}$ ) during the day of the first application in all plots. The herbicide sequencial was applied in the same manner and time as greenhouse experiment.

The field experiment was carried out in a winter fallow area, into corn stubble from the previous year, with previous natural infestation of glyphosate-resistant hairy fleabane of the six plants per $\mathrm{m}^{2}$. At 50 days before herbicide application, the hairy fleabane were cut at an average height of $10 \mathrm{~cm}$ from the soil to simulate mechanical harvest. At the time of treatments, the plants were with 50 $\mathrm{cm}$ in high and had three to five stems per plant. The plots consisted $2.0 \times 4.0$ meters.

All herbicide treatments were applied with a $\mathrm{CO}_{2}$ pressurized back-pack sprayer outfitted with four 110.02 flat-fan nozzles spaced $50 \mathrm{~cm}$ apart, calibrated to deliver $150 \mathrm{~L} \mathrm{ha}^{-1}$. Visual evaluations of the control were performed at 14, 28 and 42 days after herbicide application (DAA), where $0 \%$ indicated no injury and $100 \%$ indicated complete plant death. Additionally, the regrowth number per plant were counts at $28 \mathrm{DAA}$ (greenhouse); and in the field experiment, the regrowth was performed counting the number of sprouted stems in each plot and comparing it with the total number of stems; regrowth was expressed as a percentage at 42 DAA.

The visual evaluations of control and regrowth of hairy fleabane data were transformed, but did not improve the homogeneity of variance and data normality. Therefore, nontransformed were submitted analysis of variance (ANOVA) using the F test $(\mathrm{p} \leq 0.05)$. Mean separations for herbicides were conducted using the Scott Knott test $(\mathrm{p} \leq 0.05)$, and application time were compared using the $t$ test $(\mathrm{p} \leq 0.05)$. 


\section{RESULTS AND DISCUSSION}

\section{Greenhouse experiment (hairy fleabane rosette)}

The hairy fleabane control was influenced by interaction between herbicides treatments and time of day at 14 and 28 DAA (Table 2). The 2,4-D applied alone during the morning provided significant control compared with night time application. When 2,4-D+paraquat was applied during the night, it was more efficient compared with morning application, in both evaluations. There were no differences in efficacy between 2,4-D alone and 2,4$\mathrm{D}+$ paraquat in morning applications. In contrast, 2,4$\mathrm{D}+$ paraquat applied during the night increases hairy fleabane control by up to $28 \%$ compared with the application of 2,4-D alone. Thereby, to increase the hairy fleabane control, the 2,4-D should be applied followed by paraquat regardless of the time of day or in tank-mixtures at night, which provided the highest control (> 98\%) than 2,4-D or paraquat applied alone.
Application of dicamba during the night was $10 \%$ more effective than morning time in both evaluations (Table 2). However, dicamba plus paraquat or dicamba followed by paraquat resulted in a significant increase of hairy fleabane control regardless application time. On the other hand, paraquat provided similar control compared with dicamba at 14 DAA. Nevertheless, the control provided by paraquat and 2,4-D alone was greatest at 28 DAA than dicamba when applied during the morning. When applied at night, 2,4-D provided control at least $15 \%$ lower than dicamba and/or paraquat, which did not differ from each other.

The efficient weed control for 2,4-D when applied in the morning can be explained by enhanced absorption and translocation at high temperatures, high air humidity and the presence of light (Peterson et al., 2016). For example, 2,4-D showed high absorption and translocation in Ambrosia trifida at temperature day/night of $29 / 17^{\circ} \mathrm{C}$ compared with $20 / 11^{\circ} \mathrm{C}$ (Ganie et al., 2017). Likewise, the

Table 1: Locations, environmental data and application timings of the herbicides in greenhouse and field experiments

\begin{tabular}{|c|c|c|c|c|}
\hline \multirow{3}{*}{ Conditions } & \multicolumn{2}{|c|}{ Greenhouse } & \multicolumn{2}{|c|}{ Field } \\
\hline & $1^{\text {st }}$ application $^{\mathrm{a}}$ & $2^{\text {nd }}$ application & $\mathbf{1}^{\text {st }}$ application & $2^{\text {nd }}$ application \\
\hline & \multicolumn{2}{|c|}{ Night } & \multicolumn{2}{|c|}{ Night } \\
\hline Date & Nov 29, 2016 & Dec 05, 2016 & Nov 23, 2016 & Nov 31, 2016 \\
\hline Time & $21: 10$ & $20: 40$ & $20: 45$ & 20.30 \\
\hline Temperature & $23.1^{\circ} \mathrm{C}$ & $24.1^{\circ} \mathrm{C}$ & $22.5^{\circ} \mathrm{C}$ & $16.0^{\circ} \mathrm{C}$ \\
\hline \multirow[t]{2}{*}{ Air humidity } & $90 \%$ & $92 \%$ & $42 \%$ & $54 \%$ \\
\hline & \multicolumn{2}{|c|}{ Morning } & \multicolumn{2}{|c|}{ Morning } \\
\hline Date: & Nov 29, 2016 & Dec 06, 2016 & Nov 24, 2016 & Nov 30, 2016 \\
\hline Time & $8: 40$ & $8: 25$ & $8: 30$ & 8:00 \\
\hline Temperature & $22.6^{\circ} \mathrm{C}$ & $23.6^{\circ} \mathrm{C}$ & $19.1^{\circ} \mathrm{C}$ & $23.5^{\circ} \mathrm{C}$ \\
\hline Air humidity & $80 \%$ & $83 \%$ & $48 \%$ & $45 \%$ \\
\hline
\end{tabular}

${ }^{a} 1$ st application refers to the herbicide applied alone or in tank-mixture; 2nd application refers to sequential application of paraquat.

Table 2: Hairy fleabane ${ }^{1}$ control and regrowth at 14 and 28 DAA in response to synthetic auxins herbicides and paraquat tankmixtures applied at different times during the day. Greenhouse experiment

\begin{tabular}{|c|c|c|c|c|c|c|c|}
\hline \multirow{2}{*}{ Herbicides } & \multirow{2}{*}{$\begin{array}{c}\text { Dose } \\
(\mathrm{g} \text { ae or ai ha-1) }\end{array}$} & Morning & Night & Morning & Night & Morning & Night \\
\hline & & \multicolumn{2}{|c|}{$14 \mathrm{DAA}^{\mathrm{a}}$} & \multicolumn{2}{|c|}{28 DAA } & \multicolumn{2}{|c|}{ Regrowth } \\
\hline Control & - & $0 \mathrm{Ac}$ & $0 \mathrm{Ad}$ & $0 \mathrm{Ad}$ & $0 \mathrm{Ad}$ & - & - \\
\hline $2,4-\mathrm{D}$ & $(670)$ & $88 \mathrm{Ab}$ & $71 \mathrm{Bc}$ & $90 \mathrm{Ab}$ & $75 \mathrm{Bc}$ & $0,0 \mathrm{Ab}$ & $0,0 \mathrm{Ab}$ \\
\hline Dicamba & (378) & $78 \mathrm{Bb}$ & $88 \mathrm{Ab}$ & $80 \mathrm{Bc}$ & $90 \mathrm{Ab}$ & $0,0 \mathrm{Ab}$ & $0,0 \mathrm{Ab}$ \\
\hline Paraquat & $(400)$ & $85 \mathrm{Ab}$ & $90 \mathrm{Ab}$ & $87 \mathrm{Ab}$ & $92 \mathrm{Ab}$ & $2,0 \mathrm{Ab}$ & $0,0 \mathrm{Ab}$ \\
\hline 2,4-D+Paraquat & $(670+400)$ & $86 \mathrm{Bb}$ & $99 \mathrm{Aa}$ & $88 \mathrm{Bb}$ & $99 \mathrm{Aa}$ & $0,0 \mathrm{Ab}$ & $0,0 \mathrm{Ab}$ \\
\hline Dicamba+Paraquat & $(378+400)$ & $95 \mathrm{Aa}$ & $99 \mathrm{Aa}$ & $96 \mathrm{Aa}$ & $99 \mathrm{Aa}$ & $0,0 \mathrm{Ab}$ & $0,0 \mathrm{Ab}$ \\
\hline Paraquat & $(800)$ & $96 \mathrm{Aa}$ & $96 \mathrm{Aa}$ & $97 \mathrm{Aa}$ & $97 \mathrm{Aa}$ & $4,7 \mathrm{Aa}$ & 4,7 Aa \\
\hline 2,4-D/Paraquat & $(670 / 400)$ & $96 \mathrm{Aa}$ & $98 \mathrm{Aa}$ & $98 \mathrm{Aa}$ & $99 \mathrm{Aa}$ & $0,0 \mathrm{Ab}$ & $0,0 \mathrm{Ab}$ \\
\hline Dicamba/Paraquat & $(378 / 400)$ & $96 \mathrm{Aa}$ & $99 \mathrm{Aa}$ & $98 \mathrm{Aa}$ & $100 \mathrm{Aa}$ & $0,0 \mathrm{Ab}$ & $0,0 \mathrm{Ab}$ \\
\hline Paraquat/Paraquat & $(400 / 400)$ & $98 \mathrm{Aa}$ & $98 \mathrm{Aa}$ & $99 \mathrm{Aa}$ & $99 \mathrm{Aa}$ & $4,7 \mathrm{Aa}$ & $5,3 \mathrm{Aa}$ \\
\hline
\end{tabular}

${ }^{1}$ Rosette stage (15 - 18 leaves). ${ }^{a}$ Days after herbicide application. "+" and "/" indicate tank-mixture and sequential application, respectively. Means followed by identical uppercase letters in the row and lowercase letter in the column do not differ significantly by using the $t$ test and Scott Knott $(p<0.05)$, respectively. 
2,4-D induces the synthesis of about twice as much of ethylene when applied during the day (Sunohara \& Matsumoto, 1997). This increase in ethylene biosynthesis is a physiological indicative that the herbicide has caused effects that could lead to the plant death (Song, 2013). Another important factor is the occurrence of adequate temperature and relative humidity in the morning (Table 1), providing greater absorption and translocation of 2,4-D (Peterson et al., 2016; Ganie et al., 2017; Skelton et al., 2017).

Paraquat could be more effective when applied during the night, because as the mechanism of action is dependent on light there will be no formation of the reactive oxygen species that cause cells damage (Pitelli et al., 2011). However, there was a slight difference in weed control between the two application times, although this difference was not statistically (Table 2).

The application of 2,4-D was more effective in the rosette stage when performed during the morning, while dicamba was more efficient when applied in the night (Table 2). Similar results have been observed for the application of 2,4-D at the seedling stage of Galinsoga sp. under high light regimes, with higher weed mortality and reduced weed growth (Rai \& Triphati, 1986). Dicamba application at night has an impact on the reduction of Amaranthus palmeri roots, most likely because of effects on the translocation capacity of specific carrier protein (Johnston et al., 2018). However, according to the authors, the responses involving translocation are complex and interact with a number of factors involving physiological, molecular and genetic responses. Still, there is no information in the literature to elucidate the light effects on the translocation of synthetic auxin herbicides.

Weed control at the rosette stage can be improved by increasing herbicide doses, and to provide control greater than $95 \%$ are required $621 \mathrm{~g}$ ae ha-1 of 2,4-D and $391 \mathrm{~g}$ ae ha $^{-1}$ of dicamba (Osipe et al., 2017). On the other hand, when 2,4-D and dicamba was applies to horseweed lower than $30 \mathrm{~cm}$, efficiency did not differ significantly (Kruger et al. 2010).

There were no significant interactions between herbicides treatments and the application time for regrowth percentage. However, herbicide treatments affected hairy fleabane regrowth (Table 2). Hairy fleabane has great potential for regrowth after application of paraquat, even while providing efficient weed control (85 to 99\%). In contrast, no regrowth was observed when paraquat was applied during the night, although it was not significant when applied during the day, with two points of regrowth per plant. The regrowth percentage for paraquat treatments was not consistent with weed control and this result can be related to the variability in plant size, which had between 15 and 18 leaves. On the other hand, treatments with 2,4-D and dicamba totally inhibited regrowth.

It is worth mentioning that the hairy fleabane control provided by the tank-mixture of auxinic herbicides and paraquat applied at night was as efficient as that provided by sequential applications (Table 2). When applied in morning, weed controls was better for dicamba, either as tank-mixture or in sequential application with paraquat, and 2,4-D followed by paraquat. This suggests the use of a single application of tank-mixed herbicides to reduce application costs.

These results in part support those found by Montgomery et al. (2017), who observed that paraquat was more effective when applied at sunset, while 2,4-D was more effective when applied at middle portion of the day; for dicamba, weed control efficiency did not differ between morning and sunset applications. In our study, hairy fleabane responded differently to 2,4-D and dicamba applied during the morning and night, and the tank-mixture with paraquat will be important to determine the appropriate management of glyphosate-resistant hairy fleabane, and reducing cost of farm. Future studies are need to identify the mechanisms underlying the efficiency of herbicide tank-mixtures and of the effects of application time.

\section{Field experiment (Taller hairy fleabane)}

We observed no significant interactions between herbicides treatments and application time regarding hairy fleabane control and regrowth (Table 3). Furthermore, there was also no significant effect application time. The effects of application time might be refuted in reason of higher rate of herbicides used and weed size compared with greenhouse experiment (Mohr et al., 2007).

Dicamba was more effective in controlling hairy fleabane compared with all herbicides applied alone ; however, in first evaluation, the weed control was unsatisfactory (<68\%) (Table 3). At 28 and 42 DAA, dicamba had a control efficiency above $80 \%$, while 2,4-D and MCPA provided a control efficiency below $40 \%$ at 42 DAA. Sequential applications were more effective than use of tank-mixtures at 14 DAA, with the exception of dicamba+paraquat.

The application of 2,4-D/paraquat and dicamba/ paraquat obtained weed control ranging between 90 and $99 \%$ at $28 \mathrm{DAA}$, and dicamba+paraquat had similar control from 85 to $95 \%$ (Table 3). Although no differences were detected between the application times, and 2,4-D/ paraquat, dicamba/paraquat and dicamba+paraquat applied during night time provided slightly higher weed control (94\% to $99 \%$ ) compared with the morning application (85\% to $92 \%$ ). 
Regrowth was observed in almost all herbicide treatments, and dicamba alone and dicamba followed by paraquat provided higher regrowth reduction than other treatments (Table 3). The use of paraquat in tank-mixture with dicamba increased the potential for regrowth compared with dicamba alone; however, when dicamba was followed by paraquat, the regrowth reduction was similar to that of dicamba alone. Although significant differences were not observed between the application times, regrowth percentage was $50 \%$ for dicamba+paraquat applied in the morning and $23 \%$ when applied at night. When 2,4-D was applied in the morning, followed by paraquat, regrowth was less significant compared to application at night.

Differences in the regrowth potential among herbicides may be related to herbicide tolerance and plant stage. Kruger et al. (2010) found that dicamba provided greater control of horseweed plants larger than $30 \mathrm{~cm}$ compared with 2,4-D. Likewise, Ambrosia trifida is more susceptible to dicamba application compared with 2,4-D (Ganie \& Jhala, 2017). The translocation direction might play a role in herbicides efficiency and regrowth reduction, which occurs equally between the acropetal and basipetal directions for dicamba (Al-Khatib et al., 1992), and preferably in the basipetal direction for 2,4- D (Carson \& Bandeen, 1975). Another strategy to avoid regrowth after cutting is the application of herbicides soon after cutting or at the beginning of regrowth (Pereira et al., 2016). In this sense, auxins herbicides are important to sustain high levels of weed control, and to avoid weed regrowth (Kruger et al., 2010).

The differences between the 2,4-D and dicamba may be related to the herbicides absorption and translocation rates. High temperatures and light favor the absorption and translocation of 2,4-D (Ganie et al., 2017; Montgomery et al., 2017; Johnston et al., 2018). Thus, mild temperatures $\left(17.8^{\circ} \mathrm{C} \pm 0.9\right)$ after night application may have contributed to the low efficiency of 2,4-D. Another factor of the low efficiency of 2,4-D is hairy fleabane size $(>50 \mathrm{~cm})$ at the time of application, since translocation is preferably basipetal (Carson \& Bandeen, 1975).

On the other hand, the highest weed control capacity for dicamba, when applied at night can be attributed to mild temperatures $\left(17.8^{\circ} \mathrm{C} \pm 0.9\right)$ in the first 12 hours after herbicide application; after daytime application, the average temperature was $26.4^{\circ} \mathrm{C}( \pm 1.1)$ (data not shown). This result corroborates with those found by $\mathrm{Ou}$ et al. (2017), who found that the susceptibility of Kochia

Table 3: Hairy fleabane ${ }^{1}$ control and regrowth at 14, 28 and 42 DAA in response to synthetic aunxin herbicides and paraquat mixtures applied at different time during the day. Field experiment

\begin{tabular}{|c|c|c|c|c|c|}
\hline \multirow{2}{*}{ Herbicides } & \multirow{2}{*}{$\begin{array}{c}\text { Dose } \\
(\mathrm{g} \text { ae or ai ha-1) }\end{array}$} & Morning & Night & Morning & Night \\
\hline & & \multicolumn{2}{|c|}{14 DAA } & \multicolumn{2}{|c|}{28 DAA } \\
\hline Control & & $0 \mathrm{Ad}$ & $0 \mathrm{Ae}$ & $0 \mathrm{Ad}$ & $0 \mathrm{Ae}$ \\
\hline $2,4-\mathrm{D}$ & (1005) & $49 \mathrm{Ab}$ & $55 \mathrm{Ac}$ & $40 \mathrm{Ab}$ & $44 \mathrm{Ac}$ \\
\hline Dicamba & $(720)$ & $65 \mathrm{Ab}$ & $68 \mathrm{Ab}$ & $82 \mathrm{Aa}$ & $80 \mathrm{Ab}$ \\
\hline MCPA & (879) & $35 \mathrm{Ac}$ & $27 \mathrm{Ad}$ & $27 \mathrm{Ac}$ & $6 \mathrm{Ad}$ \\
\hline 2,4-D+Paraquat & $(1005+400)$ & $60 \mathrm{Ab}$ & $67 \mathrm{Ab}$ & $48 \mathrm{Ab}$ & $52 \mathrm{Ac}$ \\
\hline Dicamba+Paraquat & $(720+400)$ & $80 \mathrm{Aa}$ & $89 \mathrm{Aa}$ & $87 \mathrm{Aa}$ & $94 \mathrm{Aa}$ \\
\hline MCPA+Paraquat & $(879+400)$ & $58 \mathrm{Ab}$ & $64 \mathrm{Ab}$ & $28 \mathrm{Ac}$ & $33 \mathrm{Ad}$ \\
\hline 2,4-D/Paraquat & $(1005 / 400)$ & $84 \mathrm{Aa}$ & $88 \mathrm{Aa}$ & $91 \mathrm{Aa}$ & $96 \mathrm{Aa}$ \\
\hline Dicamba/Paraquat & $(720 / 400)$ & $77 \mathrm{Aa}$ & $87 \mathrm{Aa}$ & $90 \mathrm{Aa}$ & $98 \mathrm{Aa}$ \\
\hline \multirow[t]{2}{*}{ MCPA/Paraquat } & $(879 / 400)$ & $79 \mathrm{Aa}$ & $80 \mathrm{Aa}$ & $78 \mathrm{Aa}$ & $85 \mathrm{Ab}$ \\
\hline & & \multicolumn{2}{|c|}{42 DAA } & \multicolumn{2}{|c|}{ Regrowth (\%) } \\
\hline Control & & $0 \mathrm{Ad}$ & $0 \mathrm{Ae}$ & - & - \\
\hline 2,4-D & (1005) & $36 \mathrm{Ab}$ & $40 \mathrm{Ac}$ & $96 \mathrm{Aa}$ & $93 \mathrm{Aa}$ \\
\hline Dicamba & $(720)$ & $81 \mathrm{Aa}$ & $80 \mathrm{Ab}$ & $0 \mathrm{Ac}$ & $0 \mathrm{Ac}$ \\
\hline MCPA & (879) & $24 \mathrm{Ac}$ & $6 \mathrm{Ae}$ & $100 \mathrm{Aa}$ & $100 \mathrm{Aa}$ \\
\hline 2,4-D+Paraquat & $(1005+400)$ & $40 \mathrm{Ab}$ & $40 \mathrm{Ac}$ & $96 \mathrm{Aa}$ & $98 \mathrm{Aa}$ \\
\hline Dicamba+Paraquat & $(720+400)$ & $85 \mathrm{Aa}$ & $95 \mathrm{Aa}$ & $50 \mathrm{Ab}$ & $23 \mathrm{Ab}$ \\
\hline MCPA+Paraquat & $(879+400)$ & $19 \mathrm{Ac}$ & $24 \mathrm{Ad}$ & $100 \mathrm{Aa}$ & $100 \mathrm{Aa}$ \\
\hline 2,4-D/Paraquat & $(1005 / 400)$ & $90 \mathrm{Aa}$ & $96 \mathrm{Aa}$ & $27 \mathrm{Ab}$ & $67 \mathrm{Ab}$ \\
\hline Dicamba/Paraquat & $(720 / 400)$ & $92 \mathrm{Aa}$ & $99 \mathrm{Aa}$ & $1 \mathrm{Ac}$ & $0 \mathrm{Ac}$ \\
\hline MCPA/Paraquat & $(879 / 400)$ & $78 \mathrm{Aa}$ & $83 \mathrm{Ab}$ & $93 \mathrm{Aa}$ & $96 \mathrm{Aa}$ \\
\hline
\end{tabular}

${ }^{1}$ Hairy fleabane of $>50 \mathrm{~cm}$ tall. ${ }^{a}$ Days after herbicide application. "+" and "/" indicate tank-mixture and sequential application, respectively. Means followed by identical uppercase letters in the row and lowercase letter in the column do not differ significantly by using the $t$ test and Scott Knott $(\mathrm{p}<0.05)$, respectively. 
scoparia to dicamba is higher under milder temperatures, mainly due to increased dicamba absorption and translocation.

The results found were consistent with previous research in which the application of 2,4-D and dicamba alone to horseweed plants smaller than $30 \mathrm{~cm}$ provided 90 and 98\% control, respectively (Kruger et al., 2010). However in the present study 2,4-D was more effective when applied in the morning, while the opposite was found for dicamba. Similarly, paraquat in mixture with 2,4-D or dicamba provided control of 78\% for horseweed of 25-30 $\mathrm{cm}$-tall and about $90 \%$ of control for $15-20 \mathrm{~cm}$-tall plants (Eubank et al., 2008).. In other study, the weed control provide by dicamba was higher than that provided by $2,4-$ D horseweed at a height 20-25 cm (10-12 leaves) considering doses below $600 \mathrm{~g} \mathrm{ha}^{-1}$, with increasing doses, this difference disappeared (Osipe et al., 2017).

The tank-mixture containing 2,4-D or dicamba with contact herbicide provides an additive effect on weed control such as Ambrosia trifida (Ganie \& Jhala, 2017). Growth-regulating herbicides provide better results when applied at the rosette stage (Kruger et al., 2010). The use of paraquat associated with 2,4-D or dicamba is an important strategy to increase weed control, and the applications time can directly affect crop yield (Stewart $e t$ al., 2009).

\section{CONCLUSIONS}

The application of a tank-mixture of 2,4-D + paraquat should be performed preferably during the night to control hairy fleabane at the rosette stage, while for dicamba + paraquat application times has no impact on weed control. Sequential applications between synthetics auxins herbicides and paraquat were efficient regardless of the application time. Taller hairy fleabane can be more effectively controlled with dicamba + paraquat and synthetics auxins followed by paraquat. When herbicides were applied on the night, efficiency was slightly higher.

\section{ACKNOWLEDGEMENTS, FINANCIAL SUPPORT AND FULL DISCLOSURE}

The authors thank the Federal University of Santa Maria and Corteva Agriscience for the facilities to accomplish this research. The authors declare no conflict of interest. The founding sponsors had no role in the design of the study; in the collection, analyses, or interpretation of data; in the writing of the manuscript, and in the decision to publish the results.

\section{REFERENCES}

Agostinetto D, Silva DRO \& Vargas L (2017) Soybean yield loss and economic thresholds due to glyphosate resistant hairy fleabane interference. Arquivos do Instituto Biológico, 84:e0022017.
Al-Khatib K, Parker R \& Fuerst EP (1992) Foliar absorption and translocation of dicamba from aqueous solution and dicambatreated soil deposits. Weed Technology, 6:57-61.

Carson AG \& Bandeen JD (1975) Influence of ethephon on absorption and translocation of herbicides in Canada thistle. Canadian Journal of Plant Science, 55:795-800.

Eubank TW, Poston DH, Nandula VK, Koger CH, Shaw DR \& Reynolds DB (2008) Glyphosate-resistant horseweed (Conyza canadensis) control using glyphosate-, paraquat-, and glufosinatebased herbicide programs. Weed Technology, 22:16-21.

Ganie ZA \& Jhala AJ (2017) Interaction of 2,4-D or dicamba with glufosinate for control of glyphosate-resistant giant ragweed (Ambrosia trifida L.) in glufosinate-resistant maize (Zea mays L.) Frontiers Plant Science, 8:1207.

Ganie ZA, Jugulam M \& Jhala AJ (2017) Temperature influences efficacy, absorption, and translocation of 2,4-D or glyphosate in glyphosate-resistant and glyphosate-susceptible common ragweed (Ambrosia artemisiifolia) and giant ragweed (Ambrosia trifida). Weed Science, 65:588-60.

Johnston CR, Eure PM, Grey TL, Culpepper AS \& Vencill WK (2018) Time of application influences translocation of auxinic herbicides in palmer amaranth (Amaranthus palmeri). Weed Science, 66:04-14.

Kegode GO \& Fronning BE (2005) Artemisia biennis (biennial wormwood) control is influenced by plant size and weed flora at time of herbicide application. Crop Protection, 24:915-920.

Kruger GR, Davis VM, Weller SC \& Johnson WG (2010) Control of horseweed (Conyza canadensis) with growth regulator herbicides. Weed Technology, 24:425-429.

Lagator M, Vogwill T, Mead A, Colegrave N \& Neve P (2013) Herbicide mixtures at high doses slow the evolution of resistance in experimentally evolving populations of Chlamydomonas reinhardtii. New Phytologist, 198:938-945.

Lucio FR, Kalsing A, Adegas FS, Rossi CVS, Correia NM, Gazziero DLP \& Silva AF (2019) Dispersal and frequency of glyphosateresistant and glyphosate-tolerant weeds in soybean-producing edaphoclimatic microregions in Brazil. Weed Technology, $33: 217: 231$.

Martinson KB, Durgan BR, Gunsolus JL \& Sothern RB (2005) Time of day of application effect on glyphosate and glufosinate efficacy. Crop Management, 4. doi:10.1094/CM-2005-071802-RS.

Martinson KB, Sothern RB, Koukkari WL, Durgan BR \& Gunsolus JL (2002) Circadian response of annual weeds to glyphosate and glufosinate. Chronobiology international, 19:405-422.

Mohr K, Sellers BA \& Smeda RJ (2007) Application time of day influences glyphosate efficacy. Weed Technology, 21:07-13.

Montgomery GB, Treadway JA, Reeves JL \& Steckel LE (2017) Effect of time of day of application of 2,4-D, dicamba, glufosinate, paraquat, and saflufenacil on horseweed (Conyza canadensis) control. Weed Technoloy, 31:550-556.

Osipe JB, Oliveira Jr RS, Constantin J, Takano HK \& Biffe DF (2017) Spectrum of weed control with 2,4-D and dicamba herbicides associated to glyphosate or not. Planta Daninha, 35:e017160815.

Ou J, Stahlman PW \& Jugulam M (2018) Reduced absorption of glyphosate and decreased translocation of dicamba contribute to poor control of kochia (Kochia scoparia) at high temperature. Pest Management Science, 74:1134-1142.

Pereira LV, Carvalho LB \& Dal Magro T (2016) Controle químico de buva resistente a glyphosate é mais eficaz no préflorescimento ou no rebrote? Revista Ciências Agroveterinária, $15: 277-288$. 
Peterson MA, McMaster SA, Riechers DE, Skelton J \& Stahlman PW (2016) 2,4-D Past, Present, and Future: A Review. Weed Technology, 30:303-345.

Pitelli RA, Bisigatto AT, Kawaguchi I \& Pitelli RLCM (2011) Doses e horário de aplicação do diquat no controle de Eichhornia crassipes. Planta Daninha, 29:269-277.

Rai JPN \& Tripathi RS (1986) Population regulation of Galinsoga ciliata (Raf.) Blake and G. parviflora Cav.: Effect of 2,4-D application at different growth stages and light regimes. Weed Research, 26:59-67.

Sellers BA, Smeda RJ \& Johnson WG (2003) Diurnal fluctuations and leaf angle reduce glufosinate efficacy. Weed Technology, 17:302-306.

Skelton JJ, Simpson DM, Peterson Mark A \& Riechers DE (2017) Comparative analysis of 2,4-D uptake, translocation, and metabolism in non-aad-1 transformed and 2,4-D-resistant corn. Weed Science, 65:567-578.

Song Y (2013) Insight into the mode of action of 2,4 dichlorophenoxyacetic acid (2,4 D) as an herbicide. Journal of Integrative Plant Biology, 56:106-113.
Stewart CL, Nurse RE \& Sikkema PH (2009) Time of day impacts postemergence weed control in corn. Weed Technology, 23:346355 .

Stopps GJ, Nurse RE \& Sikkema PH (2013) The effect of time of day on the activity of postemergence soybean herbicides. Weed technology, 27:690-695.

Sunohara Y \& Matsumoto H (1997) Comparative physiological effects of quinclorac and auxins, and light involvement in quinclorac-induced chlorosis in corn leaves. Pesticide Biochemistry and Physiology, 58:125-132.

Vidal RA, Kalsing A, Goulart ICGR, Lamego FP \& Christoffoleti PJ (2007) Impacto da temperatura, irradiância e profundidade das sementes na emergência e germinação de Conyza bonariensis e Conyza canadensis resistentes ao glyphosate. Planta Daninha, 25:309-315.

Werth J, Walker S, Boucher L \& Robinson G (2010) Applying the double knock technique to control Conyza bonariensis. Weed Biology Management, 10:01-08. 